\title{
Content and Language Integrated Learning (CLIL) in Indonesian Context: an Overview
}

\author{
Khoiriyah \\ English Language Education Department, University of Muhammadiyah Malang, Indonesia. \\ *Corresponding email: khoiriyah230693@umm.ac.id
}

Received: 25 June $2021 \quad$ Accepted: 20 November $2021 \quad$ Published: 30 November 2021 Abstract: Content and Language Integrated Learning (CLIL) in Indonesian Context: an Overview. Objectives: this study aims to give an overview of the implementation of CLIL in the Indonesian context from recent empirical studies. Methods: a systematic literature review was employed, including searching the literature, identifying the study, coding the study, conducting a quality appraisal, and doing thematic analysis. Findings: (1) CLIL is implemented as a framework for teaching material developments, (2) CLIL has been researched to seek the effect of implementation of CLIL on content comprehension, language skills and attitude, and (3) pedagogical suggestions were highlighted including improving teachers' competence, initiating cooperation among content and language teachers and boosting students' motivation. Conclusion: CLIL research in Indonesian EFL setting has been growing significantly in recent years. Some reported that CLIL approach is also collaborated with other approaches such as bilingual education, project-based learning, task-based learning and genre-based learning.

Keywords: CLIL, Indonesia, systematic literature review, teaching approach.

Abstrak: Content and Language Integrated Learning (CLIL) di Indonesia: Suatu Tinjauan. Tujuan: penelitian ini bertujuan untuk memberikan gambaran implementasi CLIL dalam konteks Indonesia dari studi empiris terkini. Metode: studi ini menggunakan metode studi literatur yang sistematis, termasuk pencarian literatur, identifikasi studi, pengkodean studi, uji kualitas, dan analisis tematik (menggunakan program Nvivo). Temuan: (1) CLIL diimplementasikan sebagai framework untuk pengembangan bahan ajar, (2) CLIL telah diteliti untuk mencari pengaruh penerapan CLIL pada pemahaman konten, keterampilan bahasa dan sikap, dan (3) saran pedagogis yang disorot meliputi: peningkatan kompetensi guru, memprakarsai kerjasama antar guru konten dan guru bahasa, serta meningkatkan motivasi siswa. Kesimpulan: Penelitian CLIL dalam setting EFL di Indonesia telah berkembang secara signifikan dalam beberapa tahun terakhir. Beberapa melaporkan bahwa pendekatan CLIL juga dikolaborasikan dengan pendekatan lain seperti pendidikan bilingual, pembelajaran berbasis proyek, pembelajaran berbasis tugas dan pembelajaran berbasis genre.

Kata kunci: CLIL, Indonesia, ulasan literatur sistematis, pendekatan pengajaran.

\section{To cite this article:}

Khoiriyah. (2021). Content and Language Integrated Learning (CLIL) in Indonesian Context: an Overview. Jurnal Pendidikan Progresif, 11(3), 587-601. doi: 10.23960/jpp.v11.i3.202110. 


\section{INTRODUCTION}

In the last two decades, Content and Language Integrated Learning (CLIL) has certainly gained much attention among educators and practitioners in European countries and globally. This results the advancement toward the theoretical and practice-oriented framework for the implementation of CLIL in a relatively short time (Coyle, 2015). In Europe, recent reports showed that this current educational approach has been integrated into the education system in more than 40 European countries to different educational levels. Further, such as in Italy and the Netherlands, CLIL has been institutionalized in the national educational curriculum (Lopriore, 2018; van Kampen et al., 2018). Italian secondary schools officially introduce CLIL approach as a part of their national curriculum. This fact is because CLIL is one of the most innovative approaches to promote multilingualism (Fazzi \& Lasagabaster, 2020). This trend is also triggered by the belief that CLIL encourages more authentic and motivating foreign language use (Dalton-Puffer, 2011; Goris et al., 2019; Marsh, 2012):-

In Asian countries, the status of Asian Englishes might play essential roles in the globalized world, such as teaching English to accelerate national growth, understanding other cultures, and teaching English as a medium of international communication (Chang, 2011). Further, the growth of English as a Lingua Franca (henceforth ELF) has increasingly influenced English education policies and practices in many Asian countries (Kirkpatrick, 2012). ELF has become a common type of pluralistic communication among people of various language background. Because of those reasons, Content and Language Integrated Learning (CLIL) is a current pedagogical approach that often comes up in ELF discussions. CLIL is essential as a broad term that incorporates a wide variety of teaching and learning methods and activities with the dual focus, language and content learning (Mehisto et al., 2008).

Mehisto et al. (2008) provided the most widely accepted concept of Content and Language Integrated Learning (CLIL): "CLIL is a dual-focused instructional approach in which an additional language is used for the learning and teaching of both content and language" (p. 9). CLIL is a term that was coined in Europe in the 1990s to describe teaching through the medium of English. However, the term 'an additional language' does not always refer to English. This language can be any language other than the first language, including the learner's foreign language or second language (Dalton-Puffer, 2011).

Further, Dalton-Puffer (2011) and Lasagabaster (2008) summarized some CLIL characteristics that exemplify what tends to be typical of CLIL programs in Europe and many parts of Asia as follows: First, CLIL refers to the use of a foreign language or lingua franca rather than a second language (L2). The language of instruction is one that students will primarily use only in the classroom because it is not commonly used in the broader society in which students live. Second, the most common CLIL language is English, which reflects that recognizing English as an additional language is increasingly valued as a critical literacy feature worldwide. Third, CLIL also implies that teachers will be non-native speakers of the target language in most CLIL programs. Most of the time, they are content experts rather than foreign language experts. Typically, less than half of the curriculum in CLIL programs is taught in the target language. Furthermore, CLIL is most commonly used once students have mastered literacy skills in their first language (L1), which occurs more frequently in secondary than primary school (Gaudel, 2010; Pipit, 2018; van Kampen et al., 2017; Zhetpisbayeva et al., 2018). CLIL, in a nutshell, is a foreign language enrichment strategy integrated into content teaching. These 
characteristics might be partially suited to Indonesian settings.

Although CLIL approach is categorized as relatively new (Kao, 2020), CLIL can be a potential for English language teaching approach in Asia regions due to the promotion of English as an 'additional language' (Kirkpatrick, 2012). Take an example; CLIL education has been reported successful in Hongkong. In this country, English has commonly used in content classes at all educational levels (Cenoz, 2015). In the same vein, the adaptation of CLIL approach is due to the political concerns to promote the native languages such as in Philippines and Malaysia (Yang, 2016). English is still considered as a privileged in their educational system. Tainan, one of the regions in Taiwan, initiated a pilot project in 2017 that used CLIL approach as its theoretical basis for bilingual education (Chen et al., 2020). Meanwhile, in Indonesia, CLIL has been adopted as the grassroots' initiatives (Khoiriyah, 2018; Pipit, 2018; Setyaningrum \& Purwati, 2020). It means that teachers or educators implement this approach as their initiative and attempt to boost the teaching and learning process for their day-to-day teaching practice. Little attention at the regional or national level regulates the implementation of this approach.

The majority of literature review studies were concerned in the European context. Porcedda and González-Martínez (2020) reported a systematic literature review that aims to identify the gaps in CLIL teacher training and make recommendations and/or best practices. Meanwhile, Goris et al., (2019) selected several longitudinal studies regarding the effects of CLIL in order to respond to the issue of whether CLIL is justified in attributing improved L2 performance in European countries. Another review of the literature also looked into the growing trend of using English as a medium of instruction in CLIL (Rhodes, 2018). This study conducted in the
European and Swedish context to overview how CLIL affects English and mother tongue proficiency according to second language motivational and egalitarian perspective.

On the other hand, studies regarding the implementation of CLIL in Indonesian context has been underexplored. Therefore, a systematic literature review is urged to examine the extent of CLIL approach reported by the previous researchers. This article aims to highlight the practices of Content and Language Integrated Learning approach in Indonesian setting and explore some possible suggestion for better practices. It investigates how CLIL has been reported in a variety of educational level and different learning context. Notably, two research questions are formulated underneath:

1) How is the trend of CLIL research in Indonesian EFL context?

2) How is CLIL practices in Indonesian EFL context?

\section{- METHODS}

Referring to the recommendations of Okoli \& Schabram (2010) and van Wesel et al., (2015), five rigorous steps were examined to conduct this semi-systematic literature review, including searching the literature, identifying the study, coding the study, conducting a quality appraisal, and doing thematic analysis. The empirical studies and literary works are primarily chosen based on keywords used by a database of different journals. Keywords used in the quest are CLIL, EFL and Indonesia. The search was restricted to the latest research between 2015-2020 utilizing harzing's publish or perish application. Since the keywords are too general, 198 studies were found. To narrow the scope of literature, inclusion and exclusion criteria were determined. Selected studies were included based on the criteria 1) reporting CLIL as the approach, 2) 
implementing CLIL in Indonesia setting in varied educational level from primary to higher education, and 3 ) discussing CLIL and other relevant EFL approaches in Indonesia. It resulted in 37 articles were selected, referring to Indonesian context. Yet, after preliminary judgment, only 21 articles were chosen to meet this research's topic of interest.

Further, to ensure quality, only peerreviewed and full-text academic articles were appropriate for this research as it is suggested by Cronin et al. (2008). As a result, some studies were excluded, such as conference proceeding, book chapters, meta-analysis and other reports. Double references are excluded as well as articles using Bahasa Indonesia. In a nutshell, 21 journals are selected as the result of in-depth reading.

\section{Data analysis}

The last step is thematic analysis. The method of finding trends or themes in qualitative data is known as thematic analysis. A thematic analysis aims to find relevant or interesting themes in the data and use them to address the research or stress the importance of an issue (Maguire \& Delahunt, 2017). Six-guided steps were conducted, including in-depth reading to get familiar with the data, generating initial codes, searching for themes related to the research's questions, reviewing the initial themes, defining themes and writing the result (Braun \& Clarke, 2006; Peel, 2020; Vaismoradi et al., 2013). The themes will be generated based on the implementation of CLIL and some suggestions regarding the effective CLIL practice in Indonesian context using manual the qualitative data analysis.

\section{RESULT AND DISCUSSIONS}

\section{The trend of CLIL research in Indonesian EFL context}

Since a few articles have been found, a simple bibliometric analysis was used to know the trend of research regarding CLIL in Indonesian EFL settings. Firstly, the trend is generated from the research design. Overall, experimental research and $\mathrm{R} \& \mathrm{D}$ are the most desirable research design since this CLIL approach is tailored to improve the learner's language and content learning, especially for particular EFL settings in Indonesia. The choice of the researchers is also more to qualitative perspective since ethnographic and explorative research design are used to explore and get more in-depth information about the implementation of CLIL. Unfortunately, researchers are less fond of using the mixed method. The details of each publication can be seen in the following table 1 in order based on the year of publication.

Figure 1. The process of selecting appropriate publications for the study

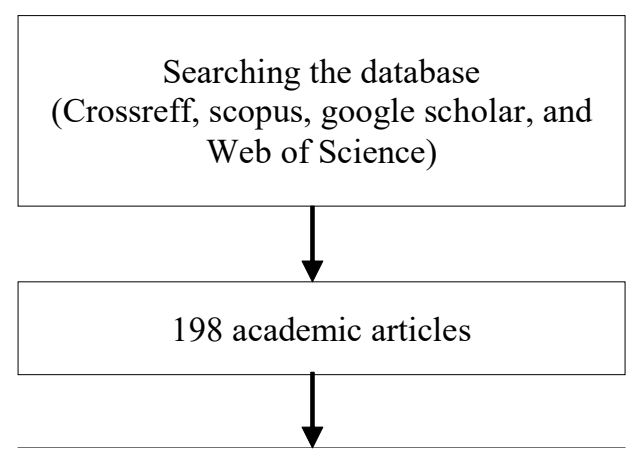

using keywords: CLIL, EFL and Indonesia

databases are too general. 


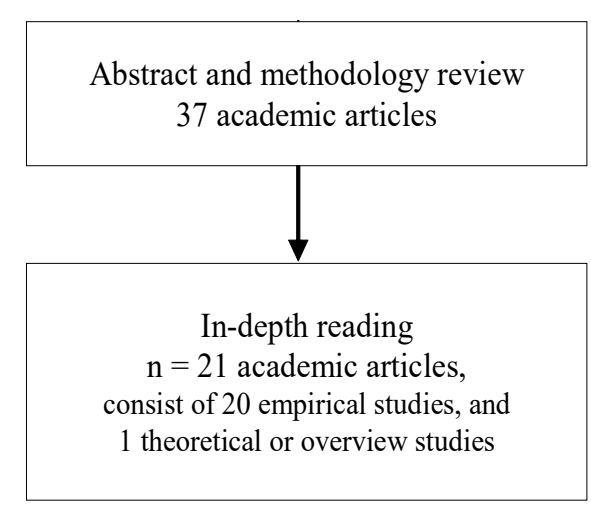

As shown in Table 1, it can be inferred that there is a growing trend of research concerning CLIL in recent years, even there were very few publications in 2017. In the recent five years, the total number of articles are 21 starting from $2016(\mathrm{n}=3), 2017(\mathrm{n}=1)$, $2018(n=4), 2019(n=5)$, to $2020(n=8)$. This increase is probably caused by several factors, such as (1) The Indonesian teachers have been attempted to find a suitable way to implement CLIL, which is successful in developing $\mathrm{n}=161$ excluded based on the research setting

$\mathrm{n}=16$ excluded (peer-reviewed and full-paper journals only)

Table 1. The result of selected journals

\begin{tabular}{|c|c|c|c|c|c|}
\hline No. & Author & Setting & Location & Focus & Type of research \\
\hline 1. & Fitriati (2016) & $\begin{array}{l}\text { Secondary } \\
\text { education }\end{array}$ & $\begin{array}{l}\text { Central Java, } \\
\text { Indonesia }\end{array}$ & $\begin{array}{l}\text { Safe-talk } \\
\text { practices }\end{array}$ & $\begin{array}{l}\text { ethnographic case study } \\
\text { (classroom observation, } \\
\text { lesson transcripts, and } \\
\text { in-depth interviews) }\end{array}$ \\
\hline 2. & $\begin{array}{l}\text { Puspitasari } \\
(2016)\end{array}$ & $\begin{array}{l}\text { Higher } \\
\text { education }\end{array}$ & $\begin{array}{l}\text { English teacher } \\
\text { training } \\
\text { program in one } \\
\text { of universities } \\
\text { in Indonesia }\end{array}$ & CLIL activities & $\begin{array}{l}\text { Explorative study } \\
\text { (in-depth interviews) }\end{array}$ \\
\hline 3. & Fitriani (2016) & $\begin{array}{l}\text { Higher } \\
\text { education }\end{array}$ & $\begin{array}{l}\text { Accounting } \\
\text { department, one } \\
\text { of universities } \\
\text { in Malang }\end{array}$ & $\begin{array}{l}\text { CLIL practice } \\
\text { reflection }\end{array}$ & $\begin{array}{l}\text { Qualitative study } \\
\text { (questionnaire and } \\
\text { interview) }\end{array}$ \\
\hline 4. & $\begin{array}{l}\text { Kusmayadi \& } \\
\text { Suryana } \\
(2017)\end{array}$ & $\begin{array}{l}\text { Secondary } \\
\text { education }\end{array}$ & in Kuningan & Writing skills & $\begin{array}{l}\text { a quasi-experimental } \\
\text { design (pre-test and } \\
\text { post-test, and } \\
\text { questionnaires) }\end{array}$ \\
\hline 5. & Pipit (2018) & $\begin{array}{l}\text { Secondary } \\
\text { education }\end{array}$ & - & $\begin{array}{l}\text { Syllabus design } \\
\text { in Math subject }\end{array}$ & $\begin{array}{l}\text { Mixed method study } \\
\text { (questionnaire, } \\
\text { interview, class } \\
\text { observation, test, and } \\
\text { the analysis of written } \\
\text { documents) }\end{array}$ \\
\hline
\end{tabular}

students' language skills in Western countries (Deswila et al., 2020); (2) In non-English speaking countries, such as Indonesia, English is still considered the most important foreign language to be taught in schools and universities (Fitriani, 2016); (3) CLIL is mostly relevant to be internal curriculum implemented as a characteristic of the university; and (4) More natural language learning condition are required to provide students more authentic English exposure (Pipit, 2018). 


\begin{tabular}{|c|c|c|c|c|c|}
\hline 6. & $\begin{array}{l}\text { Arham \& } \\
\text { Akrab (2018) }\end{array}$ & $\begin{array}{l}\text { Higher } \\
\text { education }\end{array}$ & $\begin{array}{l}\text { One of } \\
\text { universities in } \\
\text { South Sulawesi }\end{array}$ & $\begin{array}{l}\text { Lecturer's } \\
\text { perception } \\
\text { toward CLIL } \\
\text { approach }\end{array}$ & $\begin{array}{l}\text { exploratory research } \\
\text { design (interview and } \\
\text { observation) }\end{array}$ \\
\hline 7. & $\begin{array}{l}\text { Huzairin et al. } \\
(2018)\end{array}$ & $\begin{array}{l}\text { Higher } \\
\text { education }\end{array}$ & $\begin{array}{l}\text { One of } \\
\text { universities in } \\
\text { Lampung }\end{array}$ & $\begin{array}{l}\text { Materials } \\
\text { development, } \\
\text { speaking skills }\end{array}$ & $\begin{array}{l}\text { research and } \\
\text { development method }\end{array}$ \\
\hline 8. & $\begin{array}{l}\text { Setyomurdian } \\
\text { \& Subyanto } \\
(2018)\end{array}$ & $\begin{array}{l}\text { Secondary } \\
\text { education }\end{array}$ & $\begin{array}{l}\text { One of } \\
\text { vocational high } \\
\text { schools in } \\
\text { Rembang }\end{array}$ & $\begin{array}{l}\text { Material } \\
\text { developments, } \\
\text { reading skills }\end{array}$ & $\begin{array}{l}\text { research and } \\
\text { development approach } \\
(\mathrm{R} \& D)\end{array}$ \\
\hline 9. & $\begin{array}{l}\text { Nurrachmad } \\
(2019)\end{array}$ & $\begin{array}{l}\text { Higher } \\
\text { education }\end{array}$ & $\begin{array}{l}\text { One of } \\
\text { universities in } \\
\text { Solo }\end{array}$ & $\begin{array}{l}\text { the } \\
\text { implementation } \\
\text { of CLIL (based } \\
\text { on Systemic } \\
\text { Functional } \\
\text { Linguistics) }\end{array}$ & $\begin{array}{l}\text { a qualitative descriptive } \\
\text { approach (observation, } \\
\text { interview and } \\
\text { questionnaire) }\end{array}$ \\
\hline 10. & $\begin{array}{l}\text { Suhandoko } \\
(2019)\end{array}$ & $\begin{array}{l}\text { Secondary } \\
\text { education }\end{array}$ & In Jombang & $\begin{array}{l}\text { Material } \\
\text { development } \\
\text { (Biology, } \\
\text { Physics, and } \\
\text { Chemistry) }\end{array}$ & $\begin{array}{l}\text { Research \& } \\
\text { Development (R\&D) }\end{array}$ \\
\hline 11. & Sarip (2019) & $\begin{array}{l}\text { Higher } \\
\text { education }\end{array}$ & $\begin{array}{l}\text { One of } \\
\text { universities in } \\
\text { Jember }\end{array}$ & $\begin{array}{l}\text { Arabic speaking } \\
\text { skills }\end{array}$ & Action research method \\
\hline 12. & $\begin{array}{l}\text { Rachmajanti } \\
\text { and } \\
\text { Anugerahwati( } \\
\text { 2019) }\end{array}$ & $\begin{array}{l}\text { Secondary } \\
\text { education }\end{array}$ & $\begin{array}{l}\text { Several } \\
\text { secondary } \\
\text { schools }\end{array}$ & $\begin{array}{l}\text { predictor } \\
\text { variables and } \\
\text { students' } \\
\text { English learning }\end{array}$ & $\begin{array}{l}\text { correlation design } \\
\text { research (using } \\
\text { questionnaire) }\end{array}$ \\
\hline 13. & $\begin{array}{l}\text { Rohmah } \\
(2019)\end{array}$ & $\begin{array}{l}\text { Primary } \\
\text { education }\end{array}$ & $\begin{array}{l}\text { Three-selected } \\
\text { schools in East } \\
\text { java }\end{array}$ & $\begin{array}{l}\text { achievement } \\
\text { CLIL } \\
\text { implementation }\end{array}$ & $\begin{array}{l}\text { Mixed-method study } \\
\text { (semi-structured } \\
\text { interview, questionnaire } \\
\text { and test, i.e. pre-and- } \\
\text { post-test.) }\end{array}$ \\
\hline 14. & $\begin{array}{l}\text { Setyaningrum } \\
\text { et al. }(2020)\end{array}$ & $\begin{array}{l}\text { Primary } \\
\text { education }\end{array}$ & $\begin{array}{l}\text { an Islamic } \\
\text { primary school } \\
\text { located in a } \\
\text { small town near } \\
\text { Surabaya }\end{array}$ & $\begin{array}{l}\text { CLIL for } \\
\text { Science subject }\end{array}$ & $\begin{array}{l}\text { a narrative inquiry } \\
\text { (documents and } \\
\text { interviews) }\end{array}$ \\
\hline 15. & $\begin{array}{l}\text { Simbolon } \\
(2020)\end{array}$ & $\begin{array}{l}\text { Higher } \\
\text { education }\end{array}$ & $\begin{array}{l}\text { One of } \\
\text { universities in } \\
\text { Pontianak }\end{array}$ & $\begin{array}{l}\text { CLIL for a } \\
\text { maritime } \\
\text { English course }\end{array}$ & $\begin{array}{l}\text { Action research study } \\
\text { (pre-test and post-test } \\
\text { results and } \\
\text { questionnaires) }\end{array}$ \\
\hline 16. & $\begin{array}{l}\text { Nugroho } \\
(2020)\end{array}$ & $\begin{array}{l}\text { Higher } \\
\text { education }\end{array}$ & $\begin{array}{l}\text { One of } \\
\text { universities in } \\
\text { Solo }\end{array}$ & $\begin{array}{l}\text { CLIL for } \\
\text { Accounting } \\
\text { department } \\
\text { students } \\
\text { (vocabulary) }\end{array}$ & $\begin{array}{l}\text { Pre-experimental } \\
\text { research design (pre- } \\
\text { test and post-test, FGD) }\end{array}$ \\
\hline 17. & $\begin{array}{l}\text { Setyaningrum } \\
\text { \& Purwati } \\
(2020)\end{array}$ & $\begin{array}{l}\text { Primary } \\
\text { education }\end{array}$ & $\begin{array}{l}\text { In one of } \\
\text { municipalities in } \\
\text { East Java }\end{array}$ & $\begin{array}{l}\text { Report on the } \\
\text { feasibility of } \\
\text { CLIL for } \\
\text { primary school }\end{array}$ & $\begin{array}{l}\text { exploratory case study } \\
\text { (semi-structured } \\
\text { interview, observations } \\
\text { for field notes, and } \\
\text { FGD) }\end{array}$ \\
\hline
\end{tabular}


18. Surdyanto \& Kurniawan (2020)

19. Mahmud (2020)

20. Deswila et al. (2020)

21. Khairurrozikin et al. (2020)
Higher education

Secondary education

Secondary education

private boarding

Primary education school in West Sumatra

\section{One of universities in Pamulang}

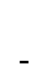

$\begin{array}{ll}\begin{array}{l}\text { Teaching } \\ \text { materials } \\ \text { development for } \\ \text { critical reading } \\ \text { course }\end{array} & \begin{array}{l}\text { Research and } \\ \text { Development (R\&D) }\end{array} \\ \begin{array}{l}\text { Report on the } \\ \text { concept of CLIL }\end{array} & \text { A descriptive study } \\ \text { in Indonesian } & \\ \text { context } & \\ \text { The } & \\ \text { implementation } & \begin{array}{l}\text { A descriptive study was } \\ \text { (observation and }\end{array} \\ \text { of CLIL for } & \text { interview) } \\ \begin{array}{l}\text { Genre } \\ \text { pedagogical subject }\end{array} & \begin{array}{l}\text { a pre-experimental } \\ \text { design (one-group } \\ \text { model and }\end{array} \\ \begin{array}{l}\text { CLIL, writing } \\ \text { skills }\end{array} & \\ \end{array}$

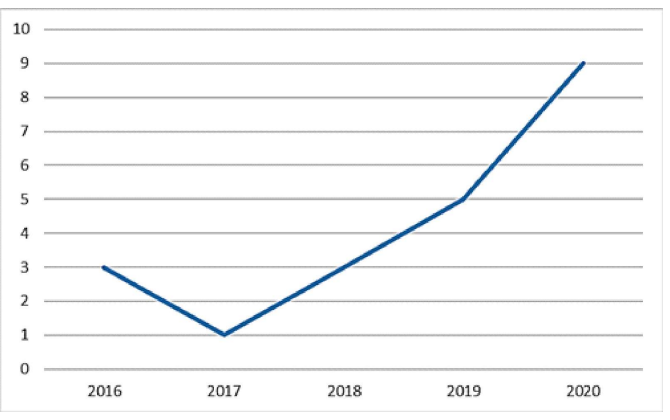

Figure 2. Number of publications per year (from 2016 to 2020 )

Meanwhile, the concentration of articles primarily heated discussion on specific issues related to CLIL implementation includes English language learning, English skills (listening, speaking, reading and writing), Teaching materials, content and language subject, curriculum and syllabus, and foreign language proficiency (See Figure 3).

Furthermore, almost all studies have been conducted in tertiary education $(n=9)$ setting compared to secondary $(n=8)$ and primary $(n=4)$ education. This is due to the current condition that CLIL is predicted suitable with the context of the vocational curriculum (Setyomurdian \&

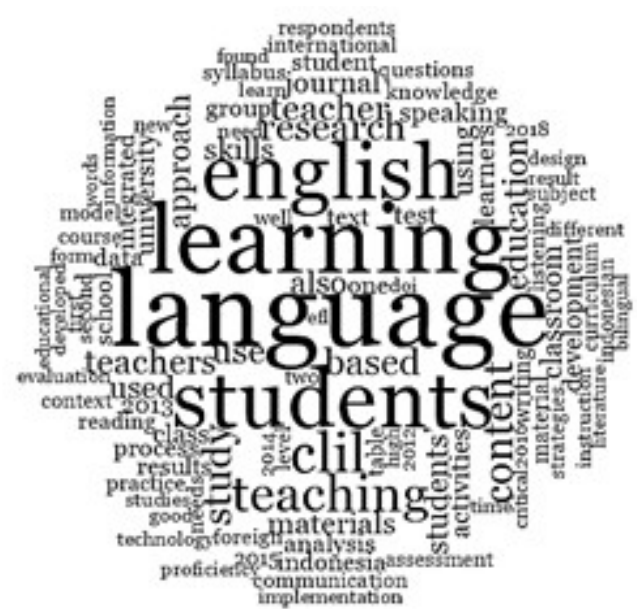

Figure 3. The word cloud indicating the research trend on CLIL implementation in Indonesian EFL setting

Subyanto, 2018). However, few studies have been conducted ien the primary school level as it is in line with Gaudel (2010); Pipit (2018); van Kampen et al. (2017); and Zhetpisbayeva et al. (2018).

\section{The implementation of CLIL in Indonesian EFL context}

This paper aims to review and analyze studies on CLIL implementation in Indonesian 
EFL settings to provide an overview and highlight some pedagogical recommendations for improving CLIL practice in Indonesia.

\section{CLIL as a framework for teaching material developments}

A number of Research and development reports have been found related to CLIL implementation in Indonesian setting. This is because CLIL effectively provides proper teaching materials for the targeted learners in different education levels. Basically, various factors, including teacher, learner, and contextual variables, influence effective instructional materials in language teaching. The availability of teaching resources in situations where the materials will be used is one of the most important contextual factors. Hence, research and development projects in education are highly recommended to validate the effectiveness of designed teaching materials. In this case, the similarity in (Huzairin et al., (2018); Pipit (, 2018); Suhandoko (, 2019); and Surdyanto \& Kurniawan, (2020)Huzairin et al. (2018), Mahmud (2020), Pipit (2018), Suhandoko (2019), Surdyanto \& Kurniawan (2020) are those with syllabus and teaching materials development which is using CLIL approach as a framework.

Suhandoko (2019) employed Research and Development (R\&D) to develop English teaching materials in the form of a coursebook prototype for tenth-graders in Indonesian senior high schools. In his study, the four frameworks of CLIL (content, cognition, communication and culture) integrated with the task-based learning model(Ellis, 2013) that underpin teaching product design serve as guidelines for selecting contents, grading materials, and sequencing tasks. Further, five subjects are involved in developing teaching materials: English, Biology, Physics, Chemistry, and Mathematics. This is based on the Curriculum 2006 for secondary education in Indonesia, and English was taught using a genre-based approach
(GBA). As a result, the simplest way to incorporate all of those contents is to create themes that cover all of them. It means the integrated topics can only be developed once the themes have been determined. Overall, six major stages were completed: needs assessment, product design, product development, validation and revision 1 , limited-field tryout and revision 2 , and final product. The validity process results demonstrate that the teaching material model is adequate and appropriate for the tenth graders. Mahmud (2020) also reported a syllabus design incorporating CLIL and GBA in teaching Biology for secondary schools in Indonesia. He presented modelling works of integrated lesson that cover the topic, language focus and content focus.

To assist learners in mastering English in a short period with high appropriacy according to the field of respected study, Huzairin et al. (2018) reported their Research and Development (R\&D) project in vocational higher education. Different from Suhandoko (2019), this study integrated the framework of CLIL and project-based learning. Dual focuses were set, including mastering English with subskills of listening, speaking, reading, writing, and developing academic knowledge. The teaching materials are designed based on the students' need in their department and finally reached their high validity result. To be specific, the result of having a rigid well-planned project led by the language lecturer revealed that project-based integrated language learning has a significant influence on the students' fluency and accuracy. Students also impressed with their learning experience. According to Surdyanto \& Kurniawan (2020), their R\&D report also proved that CLIL approach could be validated as an appropriate framework to design a critical reading course. The validity test concluded that the designed syllabus effectively improves the students' comprehension and critical thinking. 
Meanwhile, the finding from Pipit (2018) also demonstrated the same result. She attempted to propose the CLIL syllabus design within the integration of English and Maths for secondary students in collaboration with bilingual education. This is because Indonesian students have limited opportunities to speak and listen to English in their daily life even in school time. Hence, providing more artificial English environments are required to expose them to English. She assures that CLIL approach will facilitate it. Referring to the CLIL framework, the syllabus was designed carefully based on an analysis of internal and external needs. Internally, there are six types of needs analysis: target and current situation, deficiency analysis, proponent and obstacle factors, and language audit. A comprehensive need analysis involved the school principal, curriculum coordinator, and six content (Math) teachers. Externally, it is supported by examining the mathematics syllabus and textbook for syllabus content. Both need analysis are used as references for a prototype syllabus design. Proto is a syllabus that focuses on content (cognitive skills). On the other hand, some linguistics components that should be considered include topic specification, communicative function, language variation, discourse and rhetorical skill, communicative activities, grammar, and vocabulary. In general, the final product of syllabus design is expected to improve mathematics teachers' English competence and performance in the classroom.

From the previous studies, it can be concluded that CLIL approach is possibly collaborated with the framework of bilingual education, genre-based learning, project-based learning, and task-based learning to promote students' linguistic and cognitive skills. It indeed depends on the students' need and the learning environment. Teachers, both language teachers and content teachers should balance what must be taught (the content) and what can be taught in a foreign language (Coyle et al., 2010; Mehisto, 2012). Both content and language should be placed in appropriate time frames, and the designed teaching materials should produce effective results.

\section{The result of CLIL approach on Students' content comprehension, language skills and attitude}

The findings from Fitriani (2016) stated that the accounting lecturers implemented CLIL in higher education. Most students felt that CLIL implementation was interesting and challenging. By having several classroom activities such as weekly essays, quizzes, presentation and group work, they were eager to learn more about the vocabularies related to the content subject. The adapted CLIL approach helps students develop their language skills (listening, speaking, reading, and writing), as well as their vocabulary, pronunciation, and grammar. Nevertheless, CLIL makes a negligible contribution to grammar improvements. It is understandable because lecturers do not focus on grammatical consistency during teaching and learning as they do on content. Thus, CLIL is a meaning-focused learning approach in which language knowledge is used as a medium for instruction during the learning process rather than the ultimate goal of the learning (Coyle et al., 2010; Mariño, 2014; Mehisto et al., 2008).

Further, Simbolon (2020) revealed that students had a better understanding of maritime vocabulary. Students also stated how much they enjoyed the CLIL lesson. Further, in Nugroho's findings (2020), the data analysis showed that CLIL practice could significantly improve accounting students' English skills, especially vocabulary acquisition. CLIL simultaneously affect the students' attitude toward their learning process. Several aspects of CLIL practice in an English course are 
viewed positively by the students. More than half of the participants believe that learning English through a CLIL approach allows them to understand the content better. The CLIL approach appears to give participants access to more specific vocabulary and terms they would often use in their field of study. From those previous findings, it can be concluded that as one of the essential language components, improving vocabulary competence provides students with a valuable opportunity to acquire the expected content knowledge. As a result, knowing English vocabulary related to the content is critical to comprehending and gaining the content knowledge (Nugroho, 2020; Xanthou, 2011).

Meanwhile, several studies showed tangible evidence with regard to content knowledge and four language skills (listening, speaking, reading and writing). Kusmayadi \& Suryana (2017) proved that there is a significant difference in the students' writing skill since CLIL approach was tailored to the experimental group. Students are able to improve both their writing skills and their understanding of the writing content. In the same vein, action research met the expected hypothesis that using the CLIL approach. Students were able to show significant progress in understanding Arabic language as well as the fluency in Arabic speaking (Sarip, 2019). Lastly, CLILalso has a positive and vital impact on the writing skills of primary school students (Khairurrozikin et al., 2020; Setyaningrum et al., 2020). Besides, CLIL provides challenging classroom activities that help students improve their new language skills and content comprehension. Quizzes, group presentations, group teaching, and group discussions are among the classroom activities. Students perceived that those activities could assist them in achieving their learning goal of learning the language and theoretical subjects (Puspitasari, 2016).
Further, Nurrachmad (2019) reported that students rated their CLIL practice learning positively. This method allows them to easily comprehend and comprehend the content in a text structure incoherently and systematically through genre-based materials.

In general, although the results seem to corroborate CLIL's positive effect on content and language improvement, scientific research on CLIL implementation is still in its sallow discussion. In terms of the evidence regarding both content and language outcomes, previous researchers do not seem to have reached a consensus on the efficacy of the specific CLIL model. None of the studies has discussed the assessment process of CLIL outcomes, although a study recommended that CLIL can be a means for assessing students' language proficiency (Rohmah, 2019). As a result, more rigorous and longitudinal studies are needed to investigate the linguistic and academic outcomes of CLIL, especially in the context of Indonesian EFL.

\section{Suggestions for CLIL practice in Indonesian EFL context}

According to the findings of the selected studies, some of the issues discussed are related to CLIL class planning, materials design and classroom practice. Several pedagogical suggestions are highlighted. First thing first, the qualifications of teachers are a critical factor that may have an impact on the CLIL concept and its implementation (Puspitasari, 2016). The CLIL concept will be adapted to the language teaching by the content teacher who also has also knows a foreign language competence. Meanwhile, The CLIL concept will be adapted to the content teaching as well by the language teacher who also knowsalso has capability in delivering a foreign languagecontent knowledge. In the meantime, fluency in the English language is essential. Astudy by Fitriati (2016) revealed that teachers used 
safe talk strategies due to their limited proficiency in the medium of instruction. In this case, safe talk practices are language practices in which teachers and students maintain their dignity by concealing that little or no learning occurs. This safe talk, on the other hand, impedes students' second language acquisition and development.

Second, cooperation among the teachers (content and language teachers) is immensely needed. Arham \& Akrab (2018) scrutinized the CLIL practices in higher educations. They suggested that content lecturers and language lecturers should collaborate in the design of the CLIL program within the context of Indonesian higher education. As a result, language learning strategies can be mastered by content lecturers and capable of language teaching mastery without the assistance of language lecturers, allowing the maximum result to be attained and possibly perfected. Because CLIL teaching is so complex, CLIL teachers should try to collaborate with others (subject or language teachers), share best practices, and support one another. Even in primary and secondary education, to create a successful CLIL lesson, collaboration between language and content teachers should be emphasized (Setyaningrum \& Purwati, 2020). In this case, both teachers can work together to create evaluation methods to analyse the students' learning progress (Deswila et al., 2020). Furthermore, language and content teachers can ensure that the proportion of language and content aspects in a CLIL lesson is equal. Finally, the dual-focus of learning objectives, both content and language, can be achieved.

Further, maintaining the students' interest in learning a foreign language is also essential. Research from Rachmajanti \& Anugerahwati (2019) examined the relationship between several variables or predictors toward students' English learning achievement in secondary school in a CLIL context. Surprisingly, the student's interest in ELT when studying in primary education was verified and ranked as the highest contribution to the students' achievement. It means that students' interest in previous education level in foreign language affects their motivation to learn more in their higher-level education from the internal aspects. Hence, teachers should respond to create an exciting and motivating learning environment.

\section{CONCLUSIONS}

This literature overviewed the implementation of CLIL in Indonesian EFL settings. CLIL approach is considered a potential way to improve the students' learning outcomes both for content comprehension and foreign language improvement. There is significant progress in the number of CLIL studies in the recent five years. Nevertheless, most of the studies were conducted in higher education and secondary education.

In Indonesia, CLIL has implemented at a varied education level. Many scholars reported their attempts to design the syllabus and teaching materials by incorporating the CLIL framework and other approaches such as bilingual education, project-based learning, task-based learning and genre-based learning. Those, it is projected to gain an effective teaching and learning process. Meanwhile, several action research and experimental research also showed that CLIL improves the students' comprehension in both content and language skills. Additionally, students under the research show their positive attitude toward their CLIL learning experience as well. Yet, longitudinal studies are still required to prove the effectiveness of some specific CLIL design for certain Indonesian EFL settings and other 
related aspects such as students' motivation and attitude.

In addition, this current literature review comes with a few limitations. The review was limited to a select few databases since it is limited to Indonesian EFL setting. Second, some related studies are excluded since this setting is for other foreign languages such as Arabic and local languages. This research only concerns on English language teaching. However, aside from these limitations, most of the studies exploring the CLIL approach have found that CLIL is considered an appropriate teaching approach to maximize the learning process.

\section{REFERENCES}

Arham, M., \& Akrab, A. H. (2018). Delving into content lecturers' teaching capability in Content Language Integrated Learning (CLIL) at an Indonesian university. The Asian ESP Journal, 14(7.2), 68-89.

Braun, V., \& Clarke, V. (2006). Using thematic analysis in Psychology. Qualitative Research in Psychology, 3(2), 77-101. h t t p s : / / d o i org/10.1191/ 1478088706qp063oa

Cenoz, J. (2015). Content-based instruction and content and language integrated learning: the same or different? Language, Culture and Curriculum, 28(1), 8-24. https:// doi.org/10.1057/978-1-137-40737-5_5

Chang, B. (2011). The roles of English language educatrion in Asian Context. Pan-Pacific Association of Applied Linguistics, 15(1), 191-206.

Chen, F., Kao, S. M., \& Tsou, W. (2020). Toward ELF-Informed Bilingual Education in Taiwan: Addressing Incongruity Between Policy and Practice. English Teaching and Learning, 44(2), 175-191. https:// doi.org/10.1007/s42321-020-00055-1

Coyle, D. (2015). Strengthening integrated learning: Towards a new era for pluriliteracies and intercultural learning. Latin American Journal of Content and Language Integrated Learning, 8(2), 84-103. https://doi.org/10.5294/ laclil.2015.8.2.2

Coyle, D., Hood, P., \& Marsh, D. (2010). Content and language integrated learning. Cambrigde.

Cronin, P., Ryan, F., \& Coughlan, M. (2008). Undertaking a literature review/: A stepby-step approach. British Journal of Nursing, 17(1), 38-43. https://doi.org/ 10.12968/bjon.2008.17.1.28059

Dalton-Puffer, C. (2011). Content-and-language integrated learning: From practice to principles? In Annual Review of Applied Linguistics (Vol. 31,pp. 182-204). https:/ /doi.org/10.1017/S0267190511000092

Deswila, N., Kustati, M., Besral, B., \& Sukandi, S. S. (2020). Content and Language Integrated Learning (CLIL) approach across curriculum in Science classrooms: Are the English language use and learning reveal? Journal of Innovation in Educational and Cultural Research, 1(1), 15-21. https://doi.org/10.46843/ jiecr.v1i1.4

Ellis, R. (2013). Task-based language teaching: Responding to the critics. University of Sydney Papers in TESOL, 8, 1-27.

Fazzi, F., \& Lasagabaster, D. (2020). Learning beyond the classroom: students' attitudes towards the integration of CLIL and museum-based pedagogies. Innovation in Language Learning and Teaching, 113. https://doi.org/10.1080/ 17501229.2020.1714630

Fitriani, I. (2016). Grass roots' voices on the CLIL implementation in tertiary education. Dinamika Ilmu, 16(2), 211-220. https:// doi.org/10.21093/di.v16i2.320

Fitriati, S. W. (2016). Safetalk practices in 
Content and Language Integrated Learning (CLIL) classes. Language Circle: Journal of Language and Literature, 11(1), 47-58. https://doi.org/ 10.15294/lc.v11i1.7848

Gaudel, D. R. (2010). Content and Language Integrated Learning. Journal of NELTA, 11(1). https://doi.org/10.3126/ nelta.v11i1.3153

Goris, J. A., Denessen, E. J. P. G., \& Verhoeven, L. T. W. (2019). Effects of content and language integrated learning in Europe: A systematic review of longitudinal experimental studies. European Educational Research Journal, 18(6), 675-698. https:// doi.org/10.1177/1474904119872426

Huzairin, H., Sudirman, S., \& Hasan, B. (2018). Developing English learning model project based content And language integrated learning (CLIL) for English at university level in Indonesia. Advances in Social Sciences Research Journal, 5(11), 371-384. https:// doi.org/10.14738/assrj.511.5525

Kao, Y.T. (2020). Understanding and addressing the challenges of teaching an online CLIL course: a teacher education study. International Journal of Bilingual Education and Bilingualism, $0(0), 1-20$. https://doi .org/10.1080/ 13670050.2020.1713723

Khairurrozikin, M., Sukartinigsih, W., \& Subrata, H. (2020). The influence of genre pedagogical and content and language integrated learning on elementary students' writing skills. Seloka: Jurnal Pendidikan Bahasa Dan Sastra Indonesia, 9(2), 168-175. https://doi.org/10.15294/ seloka.v9i2.40099

Khoiriyah. (2018). CLIL in Indonesia: The 4C's Framework of Adopted CLIL Approach in Elementary School
Khoiriyah. Proceedings Quality Improvement Innovation in ELT (COETIN), 1, 154 160.

Kirkpatrick, A. (2012). English in ASEAN: Implications for regional multilingualism. Journal of Multilingual and Multicultural Development, 33(4), 331-344.

Kusmayadi, Y., \& Suryana, Y. (2017). Improving students' factual report writing skill by using Content and Language Integrated Learning (CLIL) method. Indonesian EFL Journal, 3(1), 21-30.

Lasagabaster, D. (2008). Foreign language competence in content and langauge integrated courses. The Online Applied Linguistics Journal, 1, 30-41.

Lopriore, L. (2018, June 1). Reframing teaching knowledge in Content and Language Integrated Learning (CLIL): A European perspective. Language Teaching Research.

Maguire, M., \& Delahunt, B. (2017). Doing a thematic analysis: A practical, step-by-step guide for learning and teaching Scholars. ALL Ireland Journal of Teaching and Learning in Higher Education (AISHEJ), 8(3), 3351-3365.

Mahmud, Y. (2020). Conceptualizing bilingual education programs through CLIL and genre-based approach: An Indonesian context. VELES Voices of English Language Education Society, 4(1), 62 74.

Mariño, C. M. (2014). Towards implementing CLIL (Content and Language Integrated Learning) at CBS (Tunja, Colombia). Colombian Applied Linguistics Journal, 16(2), 151.

Marsh, D. (2012). Content and language integrated learning ( CLIL ). A development trajectory. 
Mehisto, P. (2012). Criteria for producing CLI learning material. Encuentro, 21, 15-33. Mehisto, P., Marsh, D., \& Frigols, M. J. (2008). Uncovering CLIL.pdf.

Nugroho, A. (2020). Content and Language Integrated Learning practice in English for Accounting course. IJET (Indonesian Journal of English Teaching), 9(2), 172-181.

Nurrachmad, L. (2019). CLIL as a method in teaching sport college students through bilingual class program. Prominent Journal, 2(1), 101-116.

Okoli, C., \& Schabram, K. (2010). A guide to conducting a systematic literature review of information systems research. Working Papers on Information Systems, 10(26), 1-39.

Peel, K. L. (2020). A beginner's guide to applied educational research using thematic analysis. Practical Assessment, Research and Evaluation, 25(1), 1-16.

Pipit, M. (2018). CLIL as an alternative approach for designing English course syllabus in Indonesia. Asian EFL Journal, 20(7), 10-16.

Porcedda, M. E., \& González-Martínez, J. (2020). CLIL teacher training: lacks and suggestions from a systematic literature review. Enseñanza \& Teaching: Revista Interuniversitaria de Didáctica, 38(1), 49-68.

Puspitasari, E. (2016). Classroom activities in content and language integrated learning. Journal of Foreign Languange Teaching and Learning, 1(2), 1-13.

Rachmajanti, S., \& Anugerahwati, M. (2019). Predictors of the students' english achievement at lower secondary school: Clil context. Teflin Journal, 30(1), 7287.

Rhodes, S. (2018). The global trend towards
English-Medium Instruction: A literature review on EMI/CLIL in a Swedish and European perspective. Dalarna University.

Rohmah, I. I. T. (2019). The feasibility and effectiveness of integrating content knowledge and English competences for assessing English proficiency in CLIL. ETERNAL (English Teaching Journal), 10(1), 65-73.

Sarip, M. (2019). Improving Arabic speaking learning through content and language integrated learning approach in PSPBA FBS UNJ. Jurnal International Seminar on Languages, Literature, Arts and Education (ISLLAE), 1(1), 131-137.

Setyaningrum, R. W., \& Purwati, O. (2020). Projecting the implementation feasibility of CLIL approach for TEYL at primary schools in Indonesia. JEES (Journal of English Educators Society), 5(1), 2330 .

Setyaningrum, R. W., Setiawan, S., Anam, S., \& Retnaningdyah, P. (2020). Content and Language Integrated Learning (CLIL) in Science class during covid-19 outbreak: A narrative inquiry. ENGLISH REVIEW: Journal of English Education Volume, 9(1), 35-46.

Setyomurdian, A. N., \& Subyanto, S. (2018). The development of learning material of reading complex prosedure text with CLIL approach for vocational high school students. Seloka: Jurnal Pendidikan Bahasa Dan Sastra Indonesia, 7(2), 185-190.

Simbolon, N. E. (2020). CLIL practice in a maritime English course: EFL students' perception. EduLite: Journal of English Education, Literature and Culture, 5(2), 263-276.

Suhandoko, S. (2019). CLIL-oriented and task- 
based EFL materials development. ELT Worldwide, 6(2), 144-162.

Surdyanto, A., \& Kurniawan, W. (2020). Developing critical reading module using integrated learning content and language approach. Studies in English Language and Education, 7(1), 154-169.

Vaismoradi, M., Turunen, H., \& Bondas, T. (2013). Content analysis and thematic analysis: Implications for conducting a qualitative descriptive study. Nursing and Health Sciences, 15(3), 398-405.

van Kampen, E., Admiraal, W., \& Berry, A. (2018). Content and language integrated learning in the Netherlands: teachers' selfreported pedagogical practices. International Journal of Bilingual Education and Bilingualism, 21(2), 222-236.

van Kampen, E., Meirink, J., Admiraal, W., \& Berry, A. (2017). Do we all share the same goals for content and language integrated learning (CLIL)? Specialist and practitioner perceptions of 'ideal' CLIL pedagogies in the Netherlands. International Journal of Bilingual Education and Bilingualism, 1-17.

van Wesel, F., Boeije, H. R., \& Alisic, E. (2015). Towards a method for synthesizing diverse evidence using hypotheses as common language. Quality and Quantity, 49(6), 2237-2249.

Xanthou, M. (2011). The impact of CLIL on L2 vocabulary development and content knowledge. English Teaching: Practice and Critique, 10(4), 116-126.

Yang, W. (2016). ESP vs CLIL: A coin of two sides or a continuum of two extremes? ESP Today-Journal of English for Specific Purposes at Tertiary Level, 4(1), 43-68.
Zhetpisbayeva, B. A., Kitibayeva, A. K., Kazimova, D. A., Akbayeva, G. N., \& Zatyneiko, M. A. (2018). Assessment issues in content and language integrated learning (CLIL). Journal of Advanced Pharmacy Education and Research, 8(4), 32-38. 